\title{
Investigation of Disruptive Effect on Voltage Stability Caused by Line Contingency in Power Systems and Improvement of System Stability
}

\author{
Umut Emre Uzun ${ }^{1 *}$, Nihat Pamuk ${ }^{2}$, Sezai Taşkın ${ }^{3}$ \\ ${ }^{1 *}$ Zonguldak Bulent Ecevit University, Faculty of Engineering, Departmant of Electrical and Electronics Engineering, Zonguldak, Turkey, (ORCID: 0000-0002-6209- \\ 2962),umut.uzun@beun.edu.tr \\ ${ }^{2}$ Zonguldak Bulent Ecevit University, Faculty of Engineering, Departmant of Electrical and Electronics Engineering, Zonguldak, Turkey, (ORCID: 0000-0001-8980- \\ 6913), nihatpamuk@gmail.com \\ ${ }^{3}$ Manisa Celal Bayar University, Faculty of Engineering, Departmant of Electrical and Electronics Engineering, Manisa, Turkey, (ORCID: 0000-0002-2763-1625), \\ sezai.taskin@cbu.edu.tr
}

(1st International Conference on Applied Engineering and Natural Sciences ICAENS 2021, November 1-3, 2021)

(DOI: $10.31590 /$ ejosat.983884)

ATIF/REFERENCE: Uzun, U. E., Pamuk, N. \& Taşkın, S. (2021). Investigation of Disruptive Effect on Voltage Stability Caused by Line Contingency in Power Systems and Improvement of System Stability. European Journal of Science and Technology, (28), 56-62.

\begin{abstract}
There are many situations that cause voltage instability in power systems. One of these situations is line contingency that may occur in power systems. In this study, the effects of line contingency on the steady state are investigated in the IEEE 9 buses power system. Firstly, the static and dynamic analyses of the power system are made in normal operating condition. Continuous power flow analysis was used as static analysis and time domain simulation method were used as dynamic analysis. Then each transmission line is deactivated and the analyses are repeated. The changes in the maximum loading capacity and voltage stability of the system are investigated in case of each transmission line contingency. Finally, Static Var Compensator (SVC) is connected to the power system to improve the stability level. When the SVC is connected to the power system, the maximum loading capacity of the system is examined and the effects of this situation on the voltage stability are analyzed. All analyses are performed in the MATLAB® PSAT (Power System Analysis Toolbox). The results showed that the line contingency reduces the maximum loading capacity and deteriorates the voltage stability. It has been observed that both the problems can be eliminated with the SVC integration into the power system.
\end{abstract}

Keywords: Line contingency, Voltage stability, Maximum Loading Capacity, SVC, PSAT.

\section{Güç Sistemlerinde Hat Kopmasının Sebep Olduğu Gerilim Kararlılığındaki Bozucu Etkinin İncelenmesi ve Sistem Kararlıık Seviyesinin İyileştirilmesi}

Öz

Güç sistemlerinde gerilim kararsızlığına sebep olan pek çok durum söz konusudur. Bu durumlardan biri de güç sistemlerinde meydana gelme olasılığı her an mümkün olan hat kopmalarıdır. Bu çalışmada, IEEE 9 baralı güç sisteminde hat kopmalarının kararlı çalışma durumu üzerindeki etkileri incelenmiştir. İlk olarak güç sisteminin normal çalışma durumundaki statik ve dinamik analizleri yapılmıştır. Statik analiz olarak sürekli güç akış analizi, dinamik analiz olarak zaman domeni simülasyon metodu kullanılmıştır. Daha sonra her bir iletim hattı devre dışı bırakılarak analizler tekrarlanmıştır. Her bir iletim hattının kopması durumunda, sistemin maksimum yüklenme kapasitesindeki ve gerilim kararlılığındaki değişimler incelenmiştir. Son olarak sistemin kararlılık seviyesinin iyileştirilmesi amacıyla güç sistemine SVC (Statik Var Konpanzatör) bağlanmıştır. Güç sistemine SVC bağlı olduğu durumda, sistemin maksimum yüklenme kapasitesi incelenmiş ve bu durumun gerilim kararlılığına olan etkileri analiz edilmiştir. Tüm analizler MATLAB ${ }^{\circledR}$ PSAT (Power System Analysis Toolbox) programında gerçekleştirilmiştir. Yapılan analizler hat kopmasının maksimum yüklenme kapasitesini azalttığını ve gerilim kararlılığını bozduğunu göstermiştir. Güç sistemine SVC entegrasyonu ile her iki sorunun da düzeltilebileceği gözlemlenmiştir.

Anahtar Kelimeler: Hat kopması, Gerilim kararlılı̆̆ı, Maksimum Yüklenme Kapasitesi, SVC, PSAT.

* Corresponding Author: umut.uzun@beun.edu.tr 


\section{Introduction}

The demand for electrical energy is increasing day by day (Tosun \& Öztürk, 2020). In order to meet the increasing demand, the existing power systems are operated at full capacity in case of need. If the power system is insufficient to meet the demand, the power system is expanded with additional facilities (Kumar, Kumar, \& Sharma, 2020). The expanding power system becomes more complex and difficult to control. This situation makes it difficult to provide the power system stability. Power system stability is based on the rotor-angle, frequency and voltage stability sub-classes.

Rotor angle stability is the ability to continue operating synchronously even if the synchronous machines in the power system are exposed to a disturbance (Sutter, 2016). If any synchronous machine works faster or slower than the other machines in the power system, it causes to change in angular position between them. This situation is caused a load change on the machines and a decrease in the power transmission capacity. As the angle difference increases continuously, synchronous loss and rotor-angle instability occur.

Frequency stability is the ability of the system to remain at a constant frequency, even if there is an imbalance between the load and generation in case the power system is exposed to a disturbance (Amjady \& Fallahi, 2010). Deactivation of one or more of the synchronous machines or loads in the power system or the activation of a new energy source is caused to change in the system frequency. Frequency instability occurs as a result of frequency oscillations caused by change.

Voltage stability is the ability of all buses of the system to remain at an acceptable voltage level even when the power system is exposed to a disturbance (Kundur, 1994). There are many factors that affect voltage stability in power systems. Step change in transformers, generator fault, line length, line contingency, short circuit and overloads are the factors that cause voltage instability. As a result of these factors or when reactive power demand increases due to consumption, voltage instability may occur. Increasing reactive power demand causes a drop in the voltage level of buses, and when voltage drop continues for a long time, voltage collapse occurs (Yeşilyurt \& Akbal, 2020).

FACTS (Flexible AC Transmission System) devices are integrated into power systems in order to maintain system stability or control instability that may occur. FACTS devices perform reactive power compensation and improve system stability, transmission capacity, and power flow control. They also bring flexibility to the system (Lakkireddy, Rastgoufard, Leevongwat, \& Rastgoufard, 2015).

Dwivedi and Vadhera studied voltage stability and reactive power sustainability using different FACTS devices (Dwivedi \& Vadhera, 2019). Vardani determined the optimum location of the SVC device and examined the effect of SVC on the voltage magnitude (Vardani, 2019). In (Hermanu, Listiyanto, \& Ramelan, 2019), the effects of SVC and UPFC devices were investigated on static voltage stability. In (Kumar, Raw, Gupta, \& Kumar, 2019), the weakest bus was determined by voltage stability analysis and static analysis was performed by including SVC. In (Brillianto Apribowo, Listiyanto, \& Ibrahim, 2019), the critical buses were determined and SVC was included to the critical buses and the improvement in the voltage profile of the SVC was observed by static analysis. In (Lakkireddy, Rastgoufard, Leevongwat, \& e-ISSN: 2148-2683
Rastgoufard, 2015), SVC, STATCOM and TCSC was included in the power system. P-V curve was obtained and maximum loadability, active and reactive power losses were investigated with continuous power flow analysis. In these studies, the effects of SVC and other FACTS devices on voltage stability were investigated by only static analysis methods.

In this study, the voltage stability which is one of the system stability criteria has been examined in the IEEE 9 buses power system with both static and dynamic analysis methods. Continuation power flow analysis that is static analysis method and time domain analysis that is dynamic analysis method are performed with the MATLAB ${ }^{\circ}$ PSAT. As a result of the analyses, the effect of the FACTS device on the voltage stability is examined by placing the FACTS device in the power system.

\section{Material and Method}

In the MATLAB ${ }^{\circledR}$ PSAT, all analyses are divided into two parts, static and dynamic.

Static analysis:

- Optimal Power Flow

- Continuation Power Flow

- Phasor Measurement Unit (PMU) Placement

Dynamic Analysis:

- Small Signal Stability

- Time Domain Simulation

In this study, continuous power flow analysis is used as static analysis and time domain analysis is used as dynamic analysis.

\subsection{Continuation Power Flow Analysis}

Continuation power flow analysis is a static analysis method used to determine the stable-unstable operating region and maximum loading point in the power system. The dynamic model of a power system is generally expressed by the following equations.

$$
\begin{aligned}
& \dot{x}=f(x, y, \lambda) \\
& 0=g(x, y, \lambda)
\end{aligned}
$$

Where, $\mathrm{x}$ is called the state variable and it is a vectorial variable that contains the phase angle and angular velocity information of the generators in the power system. $y$ is called an algebraic variable and it is a vectorial variable that contains the amplitude and phase angle information of the buses in the power system. Finally, $\lambda$ is a scalar variable and it is used as loading parameter in the power system (Rosehart \& Cañizares, 1999; Dirik, 2006). Jacobian matrix is used for analysis. The Jacobian matrix of the power system is obtained from the Eq. 1 and Eq. 2.

$$
J=\left[\begin{array}{c}
J_{f} \\
J g
\end{array}\right]=\left[\begin{array}{ll}
f_{x} & f_{y} \\
g_{x} & g_{y}
\end{array}\right]=\left[\begin{array}{ll}
\frac{\partial f}{\partial x} & \frac{\partial f}{\partial y} \\
\frac{\partial g}{\partial x} & \frac{\partial g}{\partial y}
\end{array}\right]_{\left(x^{*}, y^{*}, \lambda^{*}\right)}
$$

$\left(x^{*}, y^{*}, \lambda^{*}\right)$ is the critical point of the system and it is shown in Fig. 1. This point is also called the bifurcation point (Guo \& Schlueter, 1994; Kwatny \& Pasrija, 1986). The behavior of the 
dynamic power system at the bifurcation point is examined with the $\mathrm{Jx}$ matrix which is called the system matrix. The $\mathrm{Jx}$ matrix is given in Eq.4.

$$
J_{x}=f_{x}-f_{y} \cdot g_{y}^{-1} \cdot g_{x}
$$

The determinant of $g_{y}^{-1}$ is zero at the bifurcation point. Therefore, the Jacobian matrix is singular at this point. To eliminate this problem, continuation power flow analysis is applied to the power system (Oktaviani, Barlian, Apriani, \& Syarif, 2020).

Continuation power flow analysis consists of two steps: prediction and correction. First, it is started with the known base case solution. The next case solution is found with the help of the tangent vector and the prediction step is completed. Then the solution that found using the Newton-Raphson Power Flow method is corrected. The reason for using the Newton-Raphson method is to solve nonlinear equations in the power flow (Sereeter, Vuik, \& Witteveen, 2017).

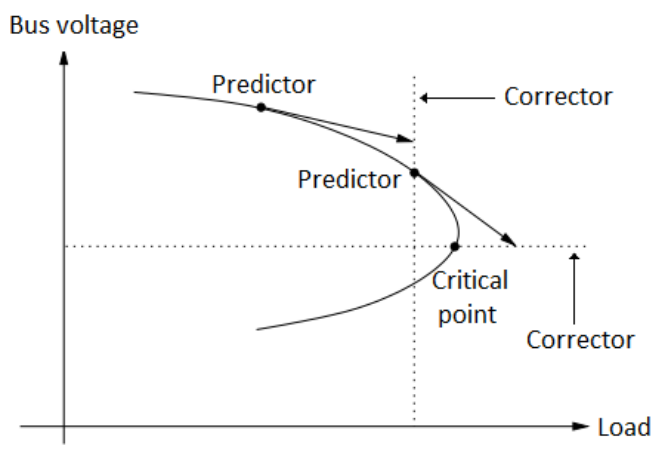

Figure 1: Voltage-loading parameter curve

\subsection{Time Domain Simulation}

Time domain simulation provides instant viewing and recording of data in the power system. Line contingeny, short circuit faults, active and reactive power values and bus voltages can be monitored in detail with time domain simulation.

Power systems are generally expressed by the differential algebraic equation given in Eq. 5 and Eq. 6 for time domain simulation (Milano-1, 2010).

$$
\begin{array}{ll}
\dot{\mathrm{x}}=f(x, y, t), & x\left(t_{0}\right)=x_{0} \\
0=g(x, y, t), & y\left(t_{0}\right)=y_{0}
\end{array}
$$

Numerical integration method is used to solve these equations. There are two approaches in the numerical integration method (Milano-2, 2005).

- $\quad$ Partitioned solution approach: In this approach, the $\mathrm{x}$ and $\mathrm{y}$ variables are solved sequentially and there is a delay time between $\mathrm{x}$ and $\mathrm{y}$ variables. This delay is avoided by iterating the $\mathrm{x}$ and $\mathrm{y}$ variables at each step. However, this can lead to numerical instability.

- Simultaneous solution approach: In this approach, $x$ and $\mathrm{y}$ variables are solved in a single step. However, this approach requires iterative computation and therefore the Jacobian matrix is used. In this case, the solution process takes a long time.
The partitioned solution approach is faster than the simultaneous solution approach, but the PSAT is used simultaneous solution approach because there is instability in the partitioned solution approach. There are two numerical integration methods that the simultaneous solution approach is used in the PSAT.

- Euler's method: This method is a first-order integration method. It gives fast results but its accuracy is not very good.

- Trapezoidal method: This method is one of the most preferred methods in solving differential algebraic equations. It has also proven reliable in the analysis of power systems.

In this study, time domain simulation is performed with trapezoidal numerical integration method. Line contingency and bus voltage levels are examined. In addition, the effect of the FACTS device on the system is also examined by time domain simulation.

\subsection{FACTS Devices}

FACTS devices are static controllers designed with various power electronics elements to control power systems faster than conventional controllers and increase power transmission capacity. They are described as static controllers because they have no moving parts (Akgün, 2006). FACTS devices have two main purposes. The first is to increase the transmission capacity of the power system. The second is to control the power flow on the transmission lines (Bhowmick, 2018; Öztürk, Bozali, \& Tosun, 2016). The devices can be used as current, voltage and impedance controllers in power systems, depending on their internal structure or user selection. Today, many FACTS devices with different structures have been developed. SVC is the most widely used in power systems, thanks to quick and easy installation.

\subsubsection{SVC}

$\mathrm{SVC}$ is a reactive power compensator connected in parallel to the circuit to control and stabilize certain parameters (especially bus voltage) of the power system (Das, Sen, Gupta, Shegaonkar, \& Acharjee, 2018). SVC is used to control the bus voltages and protect the power system by adjusting the capacitive or inductive current with the output signal.

The general structure of the SVC is formed by connecting the fixed capacitor and the TCR (Thyristor-Controlled Reactor) in parallel and is shown in Fig. 2 (Turan, Sarı, \& Koker, 2021). TCR consists of capacitive reactance connected in series with two opposite polarity thyristors connected in parallel. TCR provide the system stability by adjusting the reactive power. 


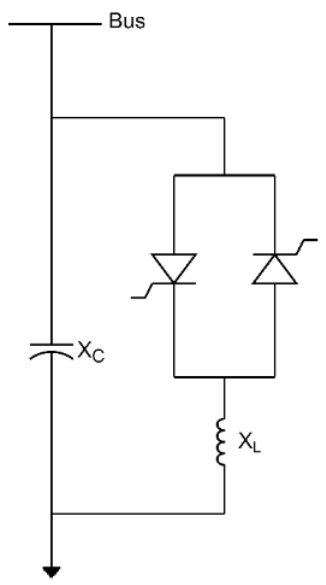

Figure 2: SVC internal structure

The reactive power expression of SVC is given in Eq. 7.

$$
Q=V^{2} \cdot b_{S V C}
$$

In the equation, the susceptance value of SVC is expressed as $\mathbf{b}_{\text {Svc }}=\mathbf{b}_{\mathbf{C}}-\mathbf{b}_{\mathrm{L}}$, where $\mathbf{b}_{\mathrm{C}}$ is the susceptance value of the fixed capacitor and $\mathbf{b}_{\mathbf{L}}$ is the susceptance value of the TCR. The dynamic structure of SVC is given in Fig. 3 (Milano-3, 2011).

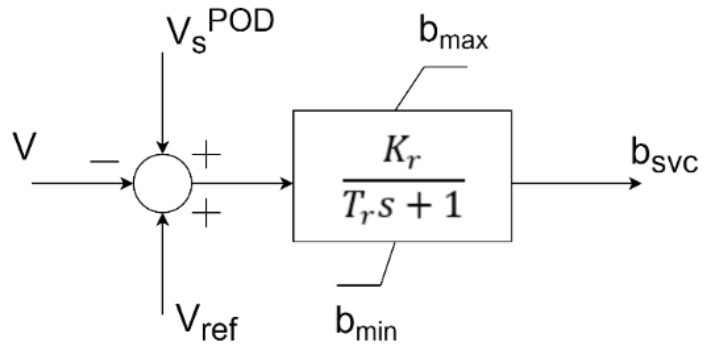

Figure 3: SVC dynamic structure

Where, $v_{\text {ref }}$ is the voltage value of the system under the normal operating conditions. $\mathcal{V}_{S}^{P O D}$ is a voltage control signal used to damp the occured oscillation (Mandour, El-Shimy, Bendary, \& Mansour, 2014). $\mathrm{Kr}$ is the gain value and $\mathrm{Tr}$ is the time constant in the dynamic structure of SVC (Shahgholian, Etesami, Shafaghi, Mahdavian, \& Leilaeyoun, 2011). Respectively, $b_{\max }$ and $b_{\min }$ are the maximum and minimum susceptance values. In case of deactivation of the capacities, it is approached to $b_{\min }$, and in case of activation, it is approached to $b_{\max }$. Thus, inductive or capacitive current can be loaded to the system by the SVC. The voltage-current characteristic of SVC is given in Fig. 4 (Gandoman, et al., 2018).

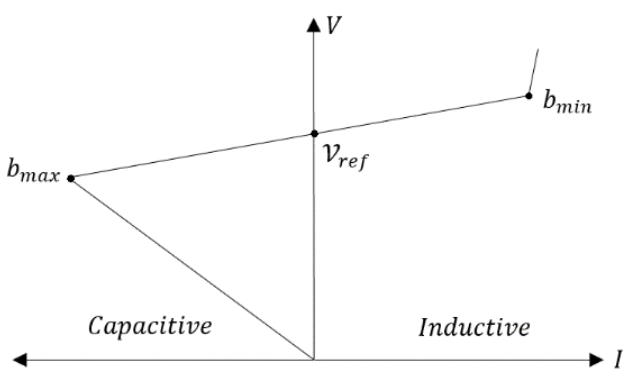

Figure 4: V-I characteristic of the SVC

\section{Material and Method}

\subsection{Results}

In this study, static and dynamic analyses are carried out using the IEEE 9 model power system given in Fig. 5. First of all, it was observed that there is no line contingency in the system and the loading parameter is $\lambda=0.8$. The system is examined statically by continuation power flow analysis method. Bus voltage profile as a result of continuation power flow analysis is given in Fig. 6 . Bus 5 has the lowest bus voltage with 0.8131 p.u.

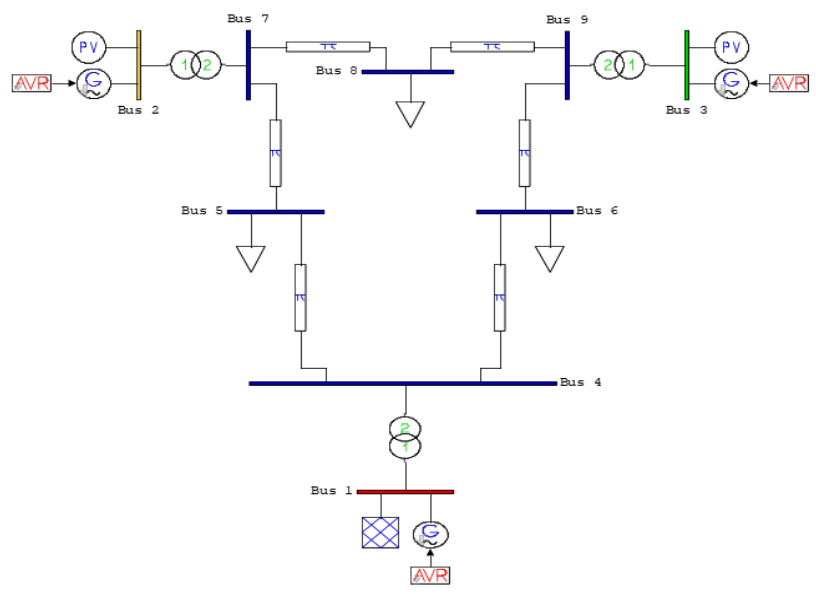

Figure 5: IEEE 9 bus power system

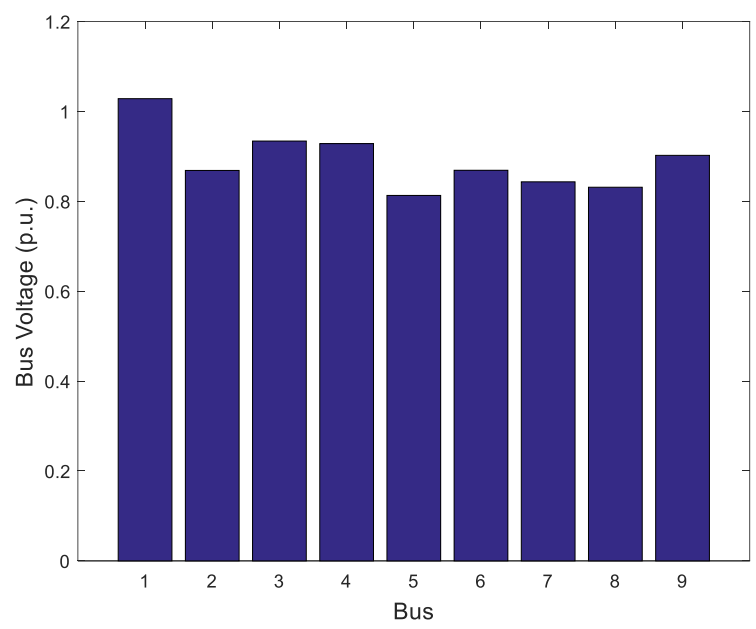

Figure 6: System bus voltage profile

The voltage-loading parameter curve of Bus 5 is given in Fig. 7. As a result of the analysis, the maximum loading parameter value was obtained as 1.6214 . 


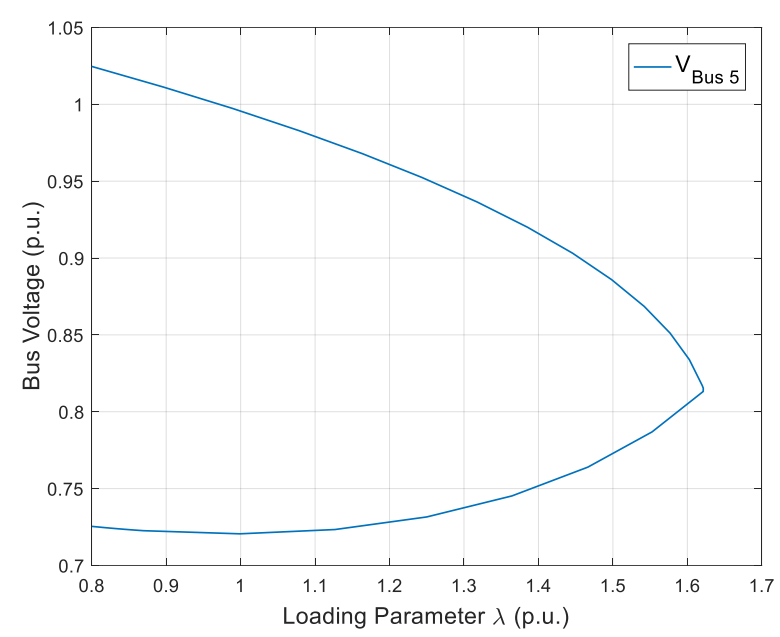

Figure 7: Bus 5 voltage-loading parameter curve

After static analysis, time domain simulation was performed for dynamic analysis. Fig. 8 shows the dynamic analysis result of Bus 5. It is observed that the bus voltage level is stable while there is no disturbances.

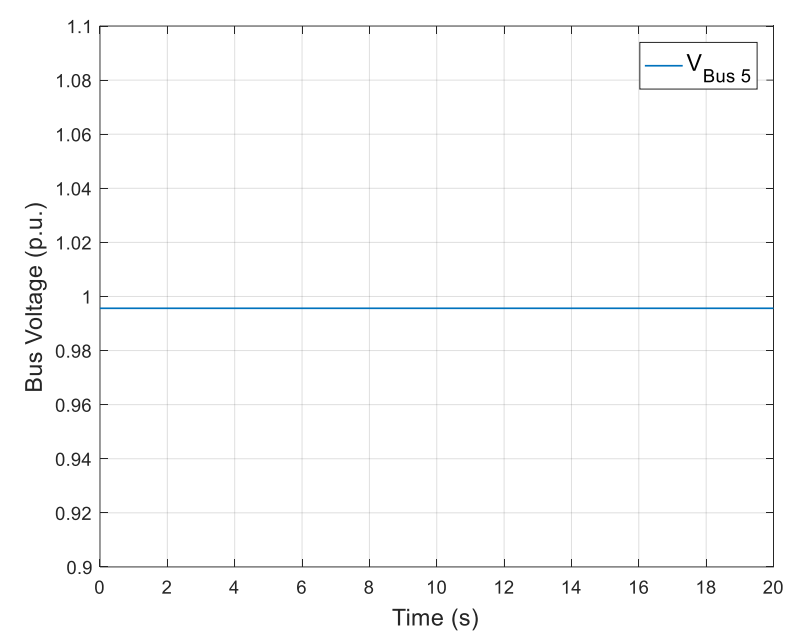

Figure 8: Bus 5 voltage-time graph

Secondly, the contingency of each line was examined in the power system after the 1 st second. The changes that observe in the maximum loading parameter in case of line contingency are given in Table 1.

Table 1. Changes in the maximum loading parameter in case of line contingency

\begin{tabular}{c|c}
\hline Transmission Line & $\begin{array}{c}\text { Maximum Loading } \\
\text { Parameter }\end{array}$ \\
\hline No contingency & 1.6214 \\
\hline $2-7$ & 1.5741 \\
\hline $3-9$ & 1.5418 \\
\hline $4-5$ & 1.1186 \\
\hline $4-6$ & 1.3681 \\
\hline
\end{tabular}

\begin{tabular}{c|c}
\hline $5-7$ & 1.3875 \\
\hline $6-9$ & 1.4431 \\
\hline $7-8$ & 1.3995 \\
\hline $8-9$ & 1.4843 \\
\hline
\end{tabular}

The biggest decrease in the maximum loading parameter was observed in the case of the contingency of line 4-5 which connected to the weakest bus. In case of the 4-5 line contingency, the voltage-loading parameter curve of Bus 5 is given in Fig. 9 and dynamic analysis result is shown in Fig. 10.

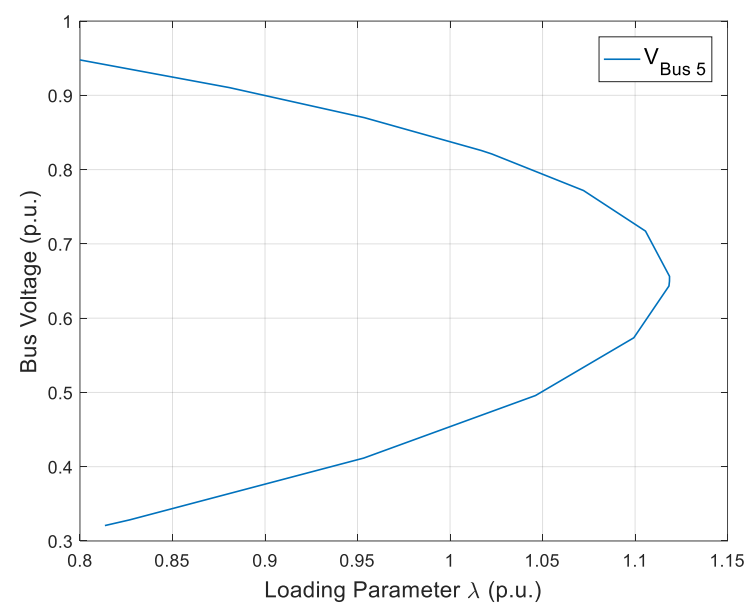

Figure 9: Bus 5 voltage-loading parameter curve in case of line contingency

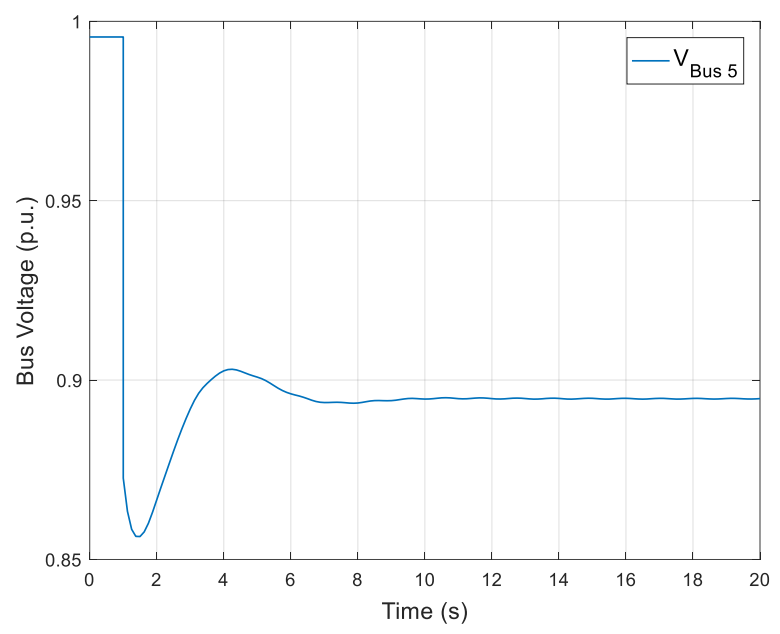

Figure 10: Bus 5 voltage-time graph in case of line contingency

As seen in Fig. 10, an instant drop occurred in bus voltage after the line contingency. After the line contingency (1. secs.), the system stabilization nearly takes $7 \mathrm{~s}$.

Finally, the analyses are repeated by connecting a 100 MVA SVC to Bus 5 that had the lowest bus voltage in the first stage and that was the lowest maximum loading parameter with the contingency of the 4-5 line in the second stage.

With the SVC connection, the continuation power flow analysis was repeated and it was observed that the maximum loading parameter increased from 1.1186 to 1.3747 . The voltageloading parameter curve of Bus 5 is given in Fig. 11 and the dynamic analysis result is given in Fig. 12. 


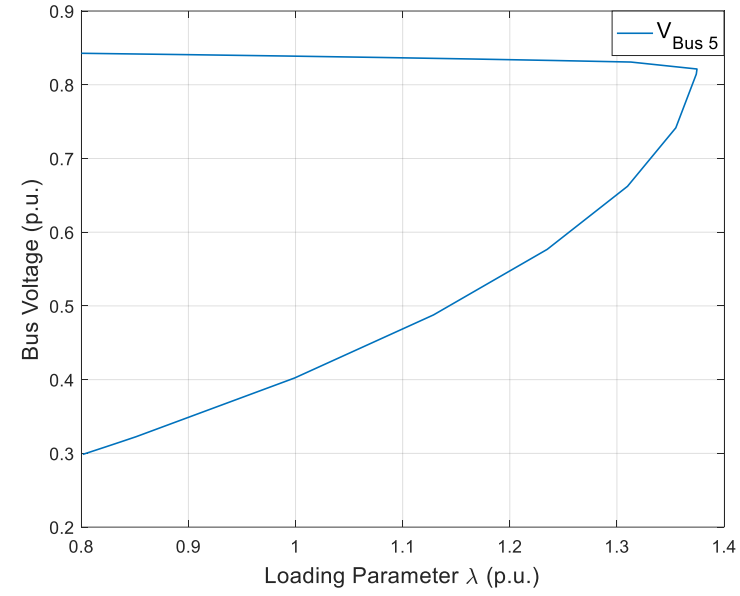

Figure 11: Voltage-loading parameter curve of Bus 5 with SVC in case of line contingency

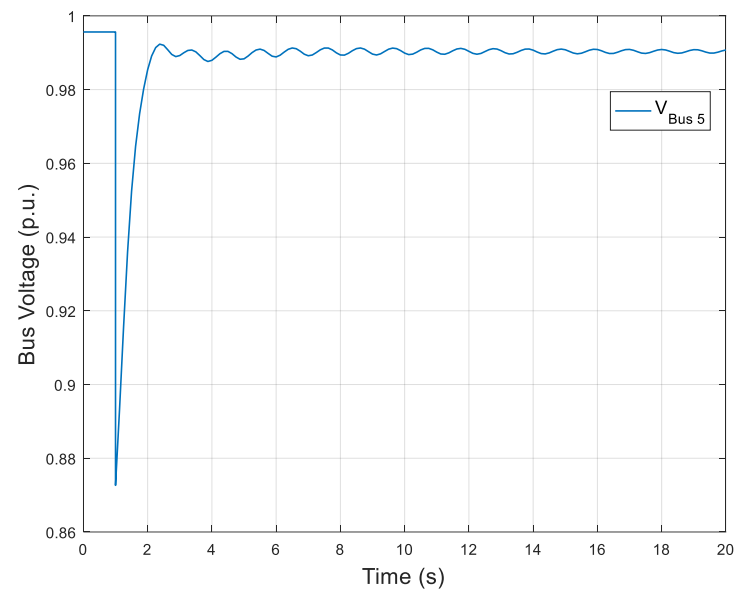

Figure 12: Voltage-time graph of Bus 5 with SVC in case of line contingency

In case of line contingency, it has been observed that the voltage value of Bus 5 drops suddenly but the bus voltage reaches its previous value in a very short time when SVC is activated. This shows that SVC improves voltage stability in case of line contingency in power systems.

\subsection{Discussion}

Voltage stability in power systems is an important issue that needs to be monitored and controlled. In this study, voltage stability analysis was performed in IEEE 9 buses power system. This analysis was repeated for three separate cases.

In the first case, $\lambda=0.8$ was selected and the power system was operated without any fault and any improvement. With the continuation power flow analysis which is a static analysis method, the voltage value of each bus was calculated and Bus 5 was determined as the weakest bus. Also, the maximum loading capacity of the system was calculated by continuation power flow analysis. With the time domain simulation which is a dynamic analysis method, the voltage level of Bus 5 was examined in the range of 0-20 seconds and it was observed that it was in a stable state.

Secondly, line contingency which is one of the potential fault situations in power systems has been examined. Respectively, each transmission line was deactivated except for lines 1-4 (because line 1-4 provides the slack bus connection, if line 1-4 is deactivated, voltage collapse occurs) after 1 second and the analyses were repeated. As a result of the static analysis, it was observed that the maximum loading capacity decreased in all transmission lines, but the greatest decrease was determined in the 4-5 line which is connected the weakest bus. As a result of the dynamic analysis, it was observed that the voltage stability of the Bus 5 deteriorated with the contingency of the 4-5 line and it took a long time to improve.

Finally, a FACTS device was connected to the system to prevent the decrease in maximum loading capacity and improve the voltage stability. As the FACTS device, the most preferred and easily controllable SVC was used in power systems. Voltage instability in Bus 5 was corrected in a short time in case of 4-5 line contingency with SVC connection. It was also observed that the maximum loading capacity increased with SVC connection.

With this study, the effect of SVC on voltage stability was investigated with dynamic analyzes in addition to static analyzes in previous studies.

\section{Conclusions and Recommendations}

In this study, it has been realized that continuation power flow analysis is an important analysis method in detecting the weakest bus, calculating the maximum loading capacity and observing the relationship between the bus voltage and maximum loading capacity. It has been proven that line contingency has a negative effect on maximum loading capacity and voltage stability in power system. With the integration of SVC into the power system, it has been observed that voltage stability has improved and maximum load capacity has increased. With the help of time domain analysis, it has been observed how the SVC behaves dynamically when a line contingency occurs in the power system.

\section{References}

Akgün, Ö. (2006). Statik Var Kompanzatör ve Tristör Kontrollü Reaktör Tasarımı (Yüksek Lisans Tezi, Niğde Üniversitesi). Niğde, Türkiye.

Amjady, N., \& Fallahi, F. (2010). Determination of frequency stability border of power system to set the thresholds of under frequency load shedding relays. Energy Conversion and Management (Elsevier), 51(10), 18641872.

Bhowmick, S. (2018). Flexible AC Transmission Systems (FACTS): Newton Power-Flow Modeling of VoltageSourced Converter-Based Controllers. CRC Press.

Brillianto Apribowo, C. H., Listiyanto, O., \& Ibrahim, M. H. (2019). Placement Static Var Compensator (SVC) for Improving Voltage Stability Based on Sensitivity Analysis : A Case Study Of 500 KV Java-Bali Electrical Power System. 6th International Conference on Electric Vehicular Technology (ICEVT).

Das, S., Sen, D., Gupta, M., Shegaonkar, M., \& Acharjee, P. (2018). Selection of Most Favourable FACTS device in Transmission Systems. IEEE 2018 International Conference on Power Energy, Environment and Intelligent Control (PEEIC) - Greater Noida, India (2018.4.13-2018.4.14)] 2018 International Conference on Power Energy, Environment and Intelligent Control (PEEIC), 550-556. 
Dirik, H. (2006). STATCOM ve SSSC Denetleyicilerinin Güç Sistemi Gerilim Kararlılı̆̆ Üzerine Etkisinin Incelenmesi( Yüksek Lisans Tezi, Ondokuz Mayıs Üniversitesi). Samsun, Türkiye.

Dwivedi, A. K., \& Vadhera, S. (2019). Reactive Power Sustainability and Voltage Stability with Different FACTS Devices Using PSAT. 6th International Conference on Signal Processing and Integrated Networks (SPIN).

Gandoman, F. H., Ahmadi, A., Sharaf, A., Siano, P., Pou, J., Hredzak, B., \& Agelidis, V. (2018). Review of FACTS technologies and applications for power quality in smart grids with renewable energy systems. Renewable and Sustainable Energy Reviews (Elsevier), 502-514.

Guo, T., \& Schlueter, R. A. (1994). Identification of Generic Bifurcation and Stability Problems in Power System Differential-Algebraic Model. IEEE Transactions on Power Systems, 9(2), 1032-1044.

Hermanu, C., Listiyanto, O., \& Ramelan, A. (2019). Comparison of Static Var Compensator (SVC) and Unified Power Flow Controller (UPFC) for Static Voltage Stability Based on Sensitivity Analysis : A Case Study of $500 \mathrm{KV}$ Java-Bali Electrical Power System. International Conference on Technologies and Policies in Electric Power \& Energy.

Kumar, L., Raw, B. K., Gupta, S. K., \& Kumar, S. (2019). Voltage Stability Enhancement Using Shunt Devices and Identification of Weak Bus through Voltage Stability Indices . 4th International Conference on Recent Trends on Electronics, Information, Communication \& Technology (RTEICT).

Kumar, S., Kumar, A., \& Sharma, N. (2020). A novel method to investigate voltage stability of IEEE-14 bus wind integrated system using PSAT. Frontiers in Energy(14(2)), 410-418.

Kundur, P. (1994). Power System Stabilty and Control. New York: McGraw-Hill.

Kwatny, H., \& Pasrija, A. B. (1986). Static bifurcations in electric power networks: Loss of steady-state stability and voltage collapse. IEEE Transactions on Circuits and Systems, 33(10), 981-991.

Lakkireddy, J., Rastgoufard, R., Leevongwat, I., \& Rastgoufard, P. (2015). Steady State Voltage Stability Enhancement Using Shunt and Series FACTS Devices . Clemson University Power Systems Conference (PSC), 1-5.

Mandour, M., El-Shimy, M., Bendary, F., \& Mansour, W. M. (2014). Damping of Power Systems Oscillations using FACTS Power Oscillation Damper - Design and Performance Analysis. 16th International Middle- East Power Systems Conference (MEPCON).

Milano-1, ,. F. (2010). Power System Modelling and Scripting. London, U.K.: Springer.

Milano-2, F. (2005). An Open Source Power System Analysis Toolbox. IEEE Transactions on Power Systems, 20(3), 1199-1206.

Milano-3, F. (2011). Power System Analysis Toolbox Documentation for PSAT version 2.1.6. https://pdfcoffee.com/qdownload/psat-documentation2011-pdf-free.html.

Oktaviani, W. A., Barlian, T., Apriani, Y., \& Syarif, N. (2020). Continuous Power Flow and Time Domain Analysis for Assessing Voltage Stability. Journal of Robotics and Control (JRC), 191-198.
Öztürk, A., Bozali, B., \& Tosun, S. (2016). Güç Sistemi Kararlılığını İyileştirecek Facts Cihazlarının Bağlantı Noktasının Belirlenmesi. Düzce Üniversitesi Bilim ve Teknoloji Dergisi, 812-825.

Rosehart, W. D., \& Cañizares, C. A. (1999). Bifurcation analysis of various power system models. International Journal of Electrical Power \& Energy Systems (Elsevier), 21(3), 171-182.

Sereeter, B., Vuik, K., \& Witteveen, C. (2017). Newton Power Flow Methods for Unbalanced Three-Phase Distribution Networks. Energies.

Shahgholian, G., Etesami, A., Shafaghi, P., Mahdavian, M., \& Leilaeyoun, A. (2011). Power System Dynamic Performance Improvement with SVC Controller . IEEE 2011 International Conference on Electrical Machines and Systems (ICEMS), 1-5.

Sutter, J. (2016). Aplication of FACTS Devices for Power System Transient Stability Enhancement (Master Thesis, Jomo Kenyatta University). Nairobi, Kenya.

Tosun, S., \& Öztürk, A. (2020). Investigation of Voltage Stability in Different Operating Conditions. El-Cezerî Journal of Science and Engineering, 7 (1), 179-188.

Turan, O., Sarı, Y., \& Koker, R. (2021). Modelling a Static VAr Compensator consist of TCR and TSC. Turkish Journal of Science \& Technology, 16(1), 11-21.

Vardani, B. (2019). Optimum Location of SVC in an IEEE 33 Bus Radial Distribution System Using Power Sensitivity Index. International Conference on Electrical, Electronics and Computer Engineering (UPCON).

Yeşilyurt, T., \& Akbal, B. (2020). Elektrik Tesislerinde Gerilim Kararlılığının Sağlanması için Kullanılan Yöntemler. Avrupa Bilim ve Teknoloji Dergisi (Özel sayı), 287-292. 